\title{
Survival of a wild ring-tailed lemur (Lemur catta) with abdominal trauma in an anthropogenically disturbed habitat
}

Anneke Moresco",", R. Scott Larsen","ll, Michelle L. Sauther $^{\mathrm{IV}}$, Frank P. Cuozzo ${ }^{\mathrm{IV}, \mathrm{V}}$, Ibrahim A. Youssouf Jacky ${ }^{\mathrm{v}}$ and James B. Millette ${ }^{\text {Iv }}$

\begin{abstract}
Soft tissue injuries are rarely reported in wild primates as these heal fast, are not obvious, and are rapidly scavenged or decompose after death. An adult female ring-tailed lemur (Lemur catta) was found to have a chronic gastrointestinal fistula in Beza Mahafaly Special Reserve, Madagascar. She was observed monthly for 13 months until her remains, which showed evidence of dog predation, were found. Until then, she was in good body condition, had gained weight from the previous year and was observed to exhibit normal behaviour and produce an infant. This report documents a wild strepsirrhine primate able to survive significant soft tissue injury in an anthropogenically disturbed habitat.
\end{abstract}

\section{RÉSUMÉ}

Il est rare que des blessures dans les tissus mous soient signalés chez les primates vivant à l'état sauvage car ces blessures guérissent rapidement, sont moins visibles ou que les animaux eux-mêmes se décomposent ou sont rapidement mangés par d'autres animaux après leur mort. Une femelle adulte de lémur catta (Lemur catta) a été trouvée avec une fistule gastro-intestinale chronique. Elle avait été observée vivante tous les mois pendant 13 mois avant que nous ne trouvions son cadavre, qui montrait des signes de prédation par de chiens. Jusque-là, elle était en bonne condition physique, avait pris du poids par rapport à I'année précédente, montrait un comportement normal et avait donné naissance à un petit. Ce rapport documente une lésion grave des tissus mous sur un Prosimien qui a été capable de survivre dans un habitat perturbé par I'homme.

\section{INTRODUCTION}

Primates are resilient and adaptable animals as evidenced by the numerous reports of wild individuals that have survived severe injuries or congenital deformities. Many of the published

\author{
Correspondence: \\ Anneke Moresco \\ Denver Zoo, 2300 Steele St. Denver, CO 80205, U.S.A. \\ E-mail: anneke_moresco@ hotmail.com
}

reports are based on museum specimens or remains, and represent skeletal fractures or abnormalities (Bramblett 1967, Chapman and Chapman 1987, Jurmain 1989, Lovell 1990, Carter et al. 2008, Chapman and Legge 2009). In the tropics, bodies of dead animals rapidly decompose or are scavenged; therefore, even if the animal is found shortly after death, bony tissues are more likely to be found than soft tissues. Long-term field studies which regularly observe individuals can provide critical context for understanding the factors leading to injury as well as how primates cope with severe injury because researchers may know the history, age and relationship of the injured animal to the group. Injured primates in regularly observed populations are likely to be found before death or shortly after death (Kanamori et al. 2012), and can provide evidence of feral animal predation or disease that can better direct conservation efforts. Since much of the primate literature on injury and illness pertains to anthropoids, most described injuries are from great apes and monkeys, rather than strepsirrhines. Among anthropoids, living within social groups and help from conspecifics are cited as reasons why individuals with injuries or congenital abnormalities fare well (Chapman et al. 1987, Turner et al. 2008, Struhsaker et al. 2011). Reports of injuries to strepsirrhines are generally cases of attacks on infants where individuals typically die within a short period of time (e.g., infanticide) (Erhart and Overdorff 1998, Jolly et al. 2000). There is one previous report of an injured adult strepsirrhine able to survive with exposed sinuses, after severe injury to the face (Junge and Sauther 2006).

\section{METHODS}

As part of a decade-long investigation into the effects of climate and habitat change on health, behaviour, ecology, and conservation of wild lemurs living within and around the Beza Mahafaly special Reserve (BMSR) in Madagascar, ten ring-tailed lemur (Lemur catta) troops have been intensively studied. Beginning

Department of Pathology, Microbiology, and Immunology, School of Veterinary Medicine, University of California, Davis, California, 95616 , U.S.A. Denver Zoo, 2300 Steele St. Denver, CO 80205, U.S.A.

Wildlife Health Center and Department of Medicine \& Epidemiology, School of Veterinary Medicine, University of California, Davis, California, 95616. U.S.A

Department of Anthropology, University of Colorado, Boulder, Colorado, 80309, U.S.A

Department of Anthropology, University of North Dakota, Grand Forks, North Dakota, 58202, U.S.A.

Faculty of Sciences, University of Toliara, Toliara (601), Madagascar. 
in 2003, annual health examinations have been performed under anaesthesia on a subset of this population (Miller et al. 2007 Sauther and Cuozzo 2008, 2009). Body measurements, dental impressions, and biological samples are obtained while lemurs are anesthetized; behavioural observations are carried out throughout the year. As part of this research, an adult female ring-tailed lemur (\#271 of Light Blue Troop), was examined on 21 June 2007 when she was three years old. The lemur was observed grooming, eating, and moving normally in the trees. The fur appeared matted and slightly darkened on the right side of the abdomen and thigh. She was anaesthetised using tiletamine-zolazepam (Telazol® Fort Dodge Animal Health, Fort Dodge, lowa) and supplemented with medetomidine (Domitor ${ }^{\circledR}$, Pfizer Animal Health, Exton, Pennsylvania) via DAN-INJECT® blow pipe, with the dart placed in the lateral distal left thigh as previously described (Larsen et al. 2011). A complete health assessment was performed including physical examination, body weight, red and white blood cell counts, differential white cell count, and serum protein (as described by Larsen et al. (2011)). Additionally, dental impressions from each quadrant and a range of body size measures were collected. Throughout examination and data collection, standard vital signs were regularly monitored and were within normal range for this population (Larsen et al. 2011). Anaesthesia was uneventful, with normal induction and recovery.

\section{RESULTS}

Upon physical examination, the lemur weighed $2.12 \mathrm{~kg}$, a normal increase in body mass over the $1.42 \mathrm{~kg}$ she weighed when first captured as a sub-adult on 29 July 2006. She was considered to be in ideal body condition, but had patchy hair loss on the lateral aspect of the right thigh and flank; the remaining hair in these regions was matted and contaminated with faecal material. During palpation, a small amount of wet, pasty faecal material extruded from a $3 \mathrm{~mm}$ diameter fistula in the lower middle aspect of the right flank (Figure 1). The material had the texture and colour of normal faeces, but was not well formed, suggesting it was from the coecum or proximal colon. The skin around the hole was pink and showed no erythema, thickening, or pus, indicating that the skin was healthy and that the injury was not actively inflamed, but rather chronic in nature an exact timeline could not, however, be determined. Several well-formed, soft faecal pellets were voided rectally during the examination, indicating that the injury was not interfering with

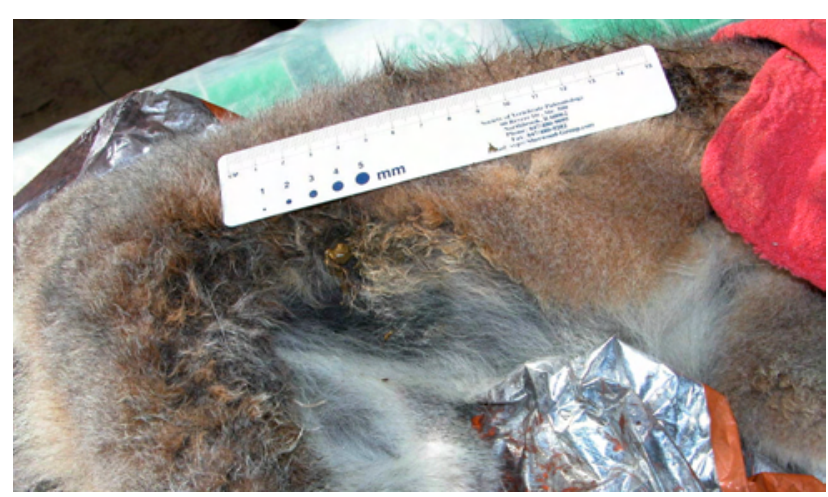

FIGURE 1. Intestinal contents extruding from a $3 \mathrm{~mm}$ diameter hole in the lower middle aspect of the right flank of wild ring-tailed lemur (Lemur catta) female \#271. The female is laying on the table with the head to the right. normal gastrointestinal passage. No other abnormalities were noted during physical examination.

Haematology values were comparable to samples taken from this population in 2003 (Miller et al. 2007) and 2007. Results from faecal examination (direct, flotation, and faecal sedimentation techniques) were negative, further indicating that she was in good health, as $50 \%$ of the examined population was positive for faecal parasites in 2007.

After overnight recovery from sedation, lemur \#271 was released in the area where she was captured the previous morning. She then exhibited normal activity and behaviour, quickly rejoining her troop. Faeces of normal consistency had been produced overnight. Several times during the week after release, she was sighted behaving normally, for example, participating with other members of her troop in repelling the intrusion of a neighbouring lemur troop.

During the birth season (September to December) troops are censused weekly to obtain accurate birth dates. On 5 October 2007, she was observed with an infant less than one week old. However by 1 November 2007 the infant was missing and was not seen again. This infant was likely to be hers given its young age and that she was seen with the infant at each weekly census until the infant was no longer observed. Although allomothering has been occasionally observed at BMSR (Whitelaw and Sauther, unpublished data), this occurs only sporadically and given the young age of the infant when it was first observed, and the fact that most female lemurs at BMSR reproduce annually, it is most likely that this infant was the offspring of \#271. Female \#271 was observed monthly through the May 2008 census but disappeared by the June 2008 census. In July 2008, a local villager reported seeing a dog with lemur remains, which were then located by our research team near the BMSR research camp in an area of degraded habitat south of the protected area. She was positively identified by her numbered collar and a subcutaneous passive integrated transponder (microchip). It was unclear whether the dog had killed the lemur or had scavenged her remains. The remains were transported to our field laboratory, and upon examination, she was estimated to have been dead approximately two weeks, with most of the soft tissue missing, autolysed, or desiccated. Most portions of the skeleton were missing, the skull had been crushed, and much of the remaining skeleton was damaged.

\section{DISCUSSION}

This report describes a wild ring-tailed lemur that was clinically healthy and able to survive 13 months, behaving normally and even reproducing, with a notable wound to the abdomen and lower gastrointestinal tract. The etiology of this injury is unknown. It may have been caused by external foreign body penetration, trauma from a predator, trauma from another lemur, penetration by an internal (ingested) foreign body, or another unknown cause. Injury due to darting during capture in 2007 is unlikely as this lemur was observed the day previous to the darting with matted hair in the region found to be the location of the injury, the injury was chronic, and dart placement in the lateral right thigh was confirmed during the physical exam. Dart placement during the 2006 capture was in the left thigh with no evidence of abdominal trauma when the animal was examined. Anaesthesia of ring-tailed lemurs at BMSR has only been performed within the context of this long-term health, behaviour, 
ecology, and conservation project beginning in 2006. Lemurs in this troop frequently raid crops adjacent to the forest. While local cultural beliefs forbid local villagers to harm a lemur in any way (Loudon et al. 2006), humans, along with their dogs, do chase lemurs from their crops and free-roaming packs of dogs chase and attack lemurs within this area as well. Trauma from teeth or claws is a possibility although there was only a single puncture wound rather than paired or multiple puncture wounds that would be expected with teeth or claws. This etiology cannot be ruled out as injuries from other teeth or claws may not have been as deep or may have healed by the time of examination. Falls during arboreal travel, especially during inter-group fights, are relatively common in arboreal primates and have been seen in ring-tailed lemurs at BMSR. In red colobus monkeys, also an arboreal species, the most common cause of injury appears to be falls which are more common in young animals than adults (Bulstrode 1990). Possibly, the wound in this young female occurred as a result of a puncture suffered during a fall. This lemur's troop's range is in an area of dramatic anthropogenic habitat degradation (Figure 2), where they are forced to travel either high in the canopy or on the ground because the forest understory has largely been removed. The potential for falls or contact with cut trees and shrubs is thus exacerbated relative to more natural habitat such as the adjacent protected area (Whitelaw 2010).

This lemur was considered healthy and able to cope with her condition at the time of examination based on her weight gain, good body condition, physical examination, normal haematology values, and observed normal behaviour immediately after anaesthesia. Her presence within the troop and normal behaviour (agonistic intergroup participation, positive social interactions) during the ensuing 13 months suggests that there was no clinical disease. She was also seen with an infant, which suggests that she was physiologically able to carry a foetus to term and successfully give birth. The cause of death of the infant is unknown. It is possible that the female's condition was associated with the infant's death; however, infant mortality in ring-tailed lemurs in this region ranges between $18-63 \%$ for the first month of life and averages $50 \%$ for the first year of life (Gould et al. 2003). Feral dogs could also be involved in the death of this infant because this female inhabited a forested region in areas of high human and feral dog activity (Whitelaw 2010).

The cause of this adult female's death is equivocal, although the bony evidence is consistent with dog predation or Scavenging. Since 2003, several of the authors and the local BMSR ecological monitoring team have observed serious attacks and

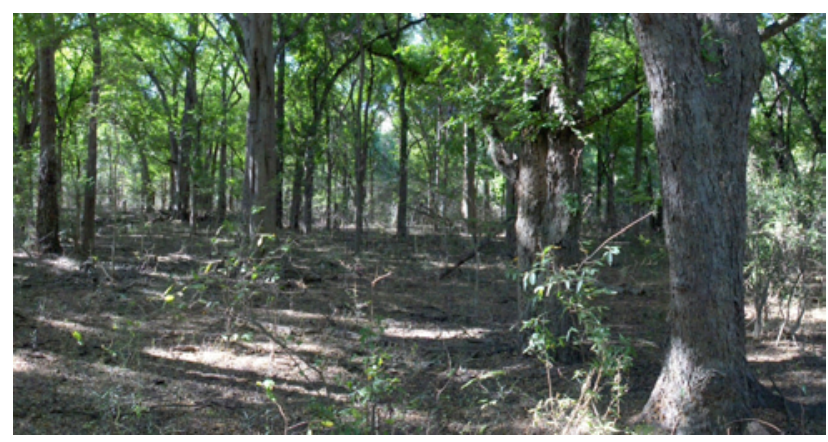

FIGURE 2. Disturbed habitat at Beza Mahafaly Special Reserve in the area where the remains of ring-tailed lemur (Lemur catta) female \#271 were found. Note the lack of understory and large trees to escape potential predators. fatal injuries on diurnal lemurs (both ring-tailed lemur (Lemur catta) and Verreaux's sifaka (Propithecus verreauxi)), by feral dogs (Brockman et al. 2008). The damage to the skull was consistent with that seen in known lemur kills by domestic dogs at BMSR, in which the head of a lemur is grasped by the dog with the mouth. For example, in 2006, a juvenile ring-tailed lemur was observed being pinned to the ground by a feral dog. This young lemur suffered severe trauma to the jaw, damaged to the point where it was unable to close its mouth and the jaw was hanging open. This lemur disappeared from the population within days of the observed dog attack.

This report is unique in that objective health measures (body weight, body condition scores, parasitology, and haematology parameters) support documentation of long-term survival of a wild strepsirrhine primate with severe soft tissue injury. The ultimate demise of this female may have been determined not by her injury, but by the habitat in which she lived, where human impact on the forest is dramatic, and where predation by feral animals is common. This report attests to the resiliency of this species and underscores the importance of controlling introduced species as part conservation efforts.

\section{ACKNOWLEDGMENTS}

We thank Elahavelo Efitroarane, Enafa and other members of the Beza Mahafaly Ecological Monitoring Team for their continued field assistance, as well as Teague O'Mara and Jennifer Ness for their assistance in 2007 and 2008. Our work was approved by the Institutional Animal Care and Use Committees of the University of North Dakota and/or the University of Colorado. All data were collected with approval of Madagascar National Parks. The work reported herein was supported by grants from the St. Louis Zoo, Primate Conservation Inc., the International Primatological Society, the University of North Dakota, North Dakota EPSCoR, the American Society of Primatologists, the Lindbergh Fund, the John Ball Zoo Society, the National Geographic Society, and the University of Colorado-Boulder. The authors also wish to thank Erik J. Moresco for help with the French summary as well as the three anonymous reviewers for their time and comments to improve the manuscript.

\section{REFERENCES}

Bramblett, C. A. 1967. Pathology in the Darajani baboon. American Journal of Physical Anthropology 6: 331-340. (doi:10.1002/ajpa.1330260308)

Brockman, D. K., Godfrey, L. R., Dollar, L. J. and Ratsirarson, J. 2008. Evidence of invasive Felis silvestris predation on Propithecus verreauxi at Beza Mahafaly Special Reserve, Madagascar. International Journal of Primatology 29: 135-152. (doi:10.1007/s10764-007-9145-5)

Bulstrode, C. 1990. What happens to wild animals with broken bones. Iowa Orthopaedic Journal 10: 19-23.

Carter, M. L., Pantzer, H., Wrangham, R. W. and Peterhans, J. K. 2008. Skeletal pathology in Pan troglodytes schweinfurthii in Kibale National Park, Uganda. American Journal of Physical Anthropology 135: 389-408. (doi:10.1002/ajpa.20758)

Chapman, C. A. and Chapman, L. J. 1987. Social responses to the traumatic injury of a juvenile spider monkey (Ateles geoffroyi). Primates 28 : 271-275. (doi:10.1007/BF02382577)

Chapman, T. J. and Legge, S. S. 2009. The dangers of multi-male groupings: trauma and healing in cercopithecoid monkeys from Cameroon. American Journal of Primatology 71: 567-573. (doi:10.1002/ajp.20689)

Erhart, E. M. and Overdorff, D. J. 1998. Infanticide in Propithecus diadema edwardsi: An evaluation of the sexual selection hypothesis. International Journal of Primatology 19: 73-81. (doi:10.1023/A:1020306910493) 
Gould, L., Sussman, R. W. and Sauther, M. L. 2003. Demographic and lifehistory patterns in a population of ring-tailed lemurs (Lemur catta) at Beza Mahafaly Reserve, Madagascar: a 15-year perspective. American Journal of Physical Anthropology 120: 182-194. (doi:10.1002/ ajpa.10151)

Jolly, A., Caless, S., Cavigelli, S., Gould, L., Pereira, M. E., Pitts, A., Pride, R. E., Rabenandrasana, H. D., Walker, J. D. and Zafison, T. 2000. Infant killing, wounding and predation in Eulemur and Lemur. International Journal of Primatology 21: 21-40. (doi:10.1023/A:1005467411880)

Junge, R. E. and Sauther, M. L. 2006. Overview on the health and disease ecology of wild lemurs: conservation implications. In: Lemurs: Ecology and Adaptation. L. Gould and M. L. Sauther (eds.), pp 423-440. Springer, New York.

Jurmain, R. 1989. Trauma, degenerative disease, and other pathologies among the Gombe chimpanzees. American Journal of Physical Anthropology 80: 29-237. (doi:10.1002/ajpa.1330800211)

Kanamori, T., Kuze, N., Bernard, H., Malim, T. P. and Kohshima, S. 2012 In press. Fatality of a wild Bornean orangutan (Pongo pygmaeus morio): behavior and death of a wounded juvenile in Danum Valley, North Borneo. Primates, published online $19^{\text {th }}$ February 2012 (doi:10.1007/ S10329-012-0297-3)

Larsen, R. S., Moresco, A., Sauther, M. L. and Cuozzo, F. P. 2011. Field anesthesia of ring-tailed lemurs (Lemur catta) using tiletamine-zolazepam, medetomidine, and butorphanol. Journal of Zoo and Wildlife Medicine 42: 75-87. (doi:10.1638/2010-0144.1)

Loudon, J. E., Sauther, M. L., Fish, K. D., Hunter-Ishiwaka, M. and Youssouf, J. I. 2006. One reserve, three primates: applying a holistic approach to understand the interconnections among ring-tailed lemurs (Lemur catta), Verreauxıs sifaka (Propithecus verreauxi), and humans (Homo sapiens) at Beza Mahafaly Special Reserve, Madagascar. Ecological and Environmental Anthropology 2: 54-74.

Lovell, N. C. 1990. Skeletal and dental pathology of free-ranging mountain gorillas. American Journal of Physical Anthropology 81: 399-412. (doi:10.1002/ajpa.1330810309)
Miller, D. S., Sauther, M. L., Hunter-Ishikawa, M., Fish, K., Culbertson, H. Cuozzo, F. P., Campbell, T. W., Andrews, G., Chavey, P. S., Nachreiner, R., Rumbeiha, W., Stacewicz-Sapuntzakis, M. and Lappin, M. R. 2007. Biomedical evaluation of free-ranging ring-tailed lemurs (Lemur catta) in three habitats at the Beza Mahafaly special reserve, Madagascar. Journal of Zoo and Wildlife Medicine 38: 201-216. (doi:10.1638/10427260)

Sauther, M. L. and Cuozzo, F. P. 2008. Somatic variation in living, wild ring-tailed lemurs (Lemur catta). Folia Primatologica 79: 55-78. (doi:10.1159/000108589)

Sauther, M. L. and Cuozzo, F. P. 2009. The impact of fallback foods on wild ring-tailed lemur biology within an anthropogenically disturbed habitat. American Journal of Physical Anthropology 140: 671-686. (doi:10.1002/ ajpa.21128)

Struhsaker, T. T., Chapman, C. A., Pope, T. R. and Marcus, J. R. 2011. Healthy baboon with no upper jaw or nose: an extreme case of adaptability in the Kibale Park, Uganda. Primates 52: 15-18. (doi:10.1007/s10329-0100224-4)

Turner, S. E., Fedigan, L. M., Nobuhara, H., Nobuhara, T., Matthews, D. H. and Nakamichi, M. 2008. Monkeys with disabilities: prevalence and severity of congenital limb malformations in Macaca fuscata on Awaji Island. Primates 49: 223-226. (doi:10.1007/s10329-008-0083-4)

Whitelaw, D. 2010. Ecological impacts of forest disturbance on ring-tailed lemurs (Lemur catta) in the Beza-Mahafaly Special Reserve region: Implications for conservation in an altered landscape. PhD Thesis. University of Colorado-Boulder

\section{SUPPLEMENTARY MATERIAL.}

AVAILABLE ONLINE ONLY.

TABLE S1. Haematology values for ring-tailed lemur (Lemur catta) female \#271 during the 2007 season and for a sub-group of the ring-tailed lemur population at Beza Mahafaly Special Reserve, Madagascar in 2007 and 2003. 